\section{THE UNIQUENESS OF THE MOTIF DESIGN IN THE COMMUNITY OF UMA UKIT BELAGA, SARAWAK}

\author{
Noria Anak Tugang \\ Universiti Malaysia Sarawak \\ Nurul Hayati Binti Rosli \\ Universiti Malaysia Sarawak
}

Nur Wafika Izzatie Binti Mohd Safar

Universiti Malaysia Sarawak

Umidie A/P Bahari

Universiti Malaysia Sarawak

Corresponding Author

hytrslee98@gmail.com
This article discusses the Uma Ukit Koyan community's unique motifs as well as the function of motifs using a qualitative method approach by conducting online interviews with residents of the Uma Ukit Koyan in Belaga, Sarawak. Based on the findings, it was found the motifs of Uma Ukit are inspired by natural elements of flora and fauna, as well as beliefs passed down through generations. Their motifs were known as hudok, such as hudok sengiro, hudok Asok/asu, hudok pusung tubak, and hudok lino/kelunan. These motifs can be found most prominently in bukui (traditional women's jewelry), singau (traditional hats), and avet (traditional carrying bag for baby). Most of the hudok created for royal descent even motifs hudok senggiro that created at avet is for babies of royal descent. The Community is also known by Ruai and has been called "Weihago" and "Letikan" that is created from rattan. One of the walls at Uma Ukit is inspired by the Sarawak vase. Finally, the motifs that inspired the Uma Ukit community were heavily influenced by aspects of their culture and life. This research is also very important in preserving the heritage so that it can be inherited by the next generation, as well as indirectly highlighting art in the world that is not limited to the Sarawak community.

Keywords: Motif art, Uma Ukit, hudok, royal descent,ruai. 


\section{INTRODUCTION}

\subsection{The State of Sarawak}

According to Dick Lembang Dugun (2019), shows that the State of Sarawak has been known as "Bumi Kenyalang", is one of the 13 States (Selangor, Perlis, Pulau Pinang, Kedah, Melaka, Negeri Sembilan, Johor, Perak, Pahang, Kelantan, Terengganu, Sabah, and Sarawak) and 3 Federal Territories (Kuala Lumpur, Putrajaya and Labuan) in Malaysia. Sarawak is also the largest state in Malaysia and a place in the Borneo eastern part of Malaysia. The state of Sarawak is also divided into 12 divisions or districts such as Kuching, Sri Aman, Sibu, Miri, Limbang, Bintulu, Sarikei, Kapit, Kota Samarahan, Mukah, Serian and Betong. Sarawak also has the largest multi-ethnic population in Malaysia. This is because the state of Sarawak has recorded a total of 27 ethnic groups, each practicing their language, culture, and way of lif e. The ethnic groups in Sarawak are like Iban, Malay Sarawak, Bidayuh, and "Orang Ulu". Ethnicities are divided according to settlement areas such as coastal areas, river valleys, inland districts, and even upland areas. This situation has created each ethnic group that forms their respective cultural identity according to its environment. Sarawak or "Bumi Kenyalang" is famous for its unique, interesting, and harmonious ethnic diversity. The uniqueness and harmony that the state of Sarawak has provided as one of the most harmonious states without the emergence of racial problems in the various ethnic groups in the state. The harmony has also created unity and political stability that can stimulate good economic growth and improvement for the state of Sarawak.

\subsection{The Community of Uma Ukit Koyan}

The "Orang Ulu" or translated as "people of the interior" are made up of 26 different ethnic groups such as the Kenyah, Kayan, Kelabit, Kajang, Murut, Penan, Saban, Tabun, Ukit, Punan, and others. Therefore, the community of Uma Ukit or ethnic is one of the tribes under the "Orang Ulu" community in Sarawak. This ethnic group is also a community with a small minority. In 2019, this community consisting of about 650 residents and 79 households only and lives in Sungai Asap Koyan, in Belaga Sarawak (Sarawak energy, 2020). Belaga district is located in the upper reaches of Rejang and various international borders with North Kalimantan which is part of the territory of Indonesia. Belaga is a hilly and mountainous area (Roselind et al., 2015).

According to Astro Awani News (2019), titled "Mengangkat legasi Sarawak dalam perniagaan pakaian" stated the motifs are the main subject in a work of art that aims to beautify a work of art. Certain motifs are also applied to symbolize the identity of each ethnic group in the "Bumi Kenyalang" which is greatly influenced by environmental factors and their own beliefs. Every hand motif art that is produced so meticulously, delicately, and uniquely has made the motifs art produced by ethnic groups in Sarawak. 
Sarawak also was named one of the best artworks in the world. Although, the community of Uma Ukit Koyan in Belaga, Sarawak is less known to the public.

The wealth of art produced by ethnicities has also produced a very proud art variation. If we look, the motifs art found in the weaving and carving of the Uma Ukit Koyan community in Belaga, Sarawak is indirectly able to ref lect the cultural aspects and beliefs of the community. Therefore, the uniqueness of the motif art produced by the community should be further highlighted to the general public so that the art produced by the community is better than their known art.

\section{OBJECTIVES OF THE RESEARCH}

1. To identify the types of motifs found in the Uma Ukit Koyan community in Belaga, Sarawak.

2. To analyze the function of motifs that available on Uma Ukit Koyan community in Belaga, Sarawak.

\section{LITERATURE REVIEW}

It is common knowledge that every state in Malaysia must have its art pattern or motifs that can symbolize a community or ethnicity. Sarawak is also one of the states in Malaysia which are well known as a state rich in artistic and cultural heritage. Sarawak has also produced many of its art patterns or motifs. Most of the arts such as motifs will be self-produced by the ethnic groups in Sarawak.

According to, Nasaruddin Stanley Kujat (2021), in Radio Television Malaysia (RTM) titled "Cerita Pagi Sarawak-Ruai Rotan Uma Ukit", stated perhaps a village for the Uma Ukit ethnic group is foreign to the outside community who do not know or are aware of the existence of the ethnic group. However, in the Sungai Asap area and the Belaga district, it is no longer unfamiliar with the ethnic group named Uma Ukit. Little information, this ethnic group is an ethnic group under the "Orang Ulu" community. However, this ethnic group is less known than the Kayan and Kenyah ethnic groups. This is because the Uma Ukit ethnic group is an ethnic group with a small population. Based on the news interview, the Uma Ukit Koyan ethnic group has a longhouse that has been decorated with rattan. This is because, in every part of the house wall, the chairs up to the pillars of their longhouse are all made using rattan. The use of rattan has attracted the attention of many with its uniqueness and special features displayed.

Not only that, but the walls of the ethnic longhouses decorated with rattan also show art motifs that can symbolize their culture and way of life. The relationship between the handicrafts of the "Orang Ulu" community and the Uma Ukit Koyan ethnic group in 
Belaga, Sarawak does not show significant differences. The motifs in art produced are also almost identical. Raw materials such as rattan as well as the use of beads which are considered cultural are also used by the Uma Ukit ethnic group. It will be adapted (Kujat, 2021) on the products of bags, baskets, house walls, home decoration appliances, hats, etc. The mat is a very well-known production among the Ulu people, Sarawak. 'Bat/Pat' and 'Bat/Pat Dapit' is a reference among the Orang Ulu community to the mat used as a base for a bed or seat. The community will also refer to the mat as a dining paddy or other substances as a perceptionto avoid disrespecting the guests or incorrect use.

According to Salmah Omar, Philip Lepun, and Ribka Alan (2016) in the Journal of Society and Space, stated about Ethnicity and the Shaping of the Malaysian Cultural Landscape: The Art of Mat Weaving of the Ulu Sarawak People, the "Orang Ulu" community produces mats that are very important in their use because they are closely related to the order of degrees of hierarchy. The community also relates to ownership or preparation of mats in a family to avoid the incorrect interpretation of the Ulu community or others for those who visit the house to understand their culture. Besides, to illustrate the real-life that exists among the community or family in the Orang Ulu community, the pattern, and type of mat is an important indicator in society.

According to Lydia Patrick Padri, Intan Khasumarlina Mohd Khalid, and Harozila Ramil (2015), in the "Jurnal Seni dan Pendidikan Seni", and title of The Motifs of Kalong in Sarawak, stated the Kalong motifs in "Orang Ulu" community symbolizes something or carrying good symbols based on philosophy, tradition, legend, and history. The symbolic motifs produced have the mystical affiliation contained in the equation between the words specified in each object's name. As a result, each of the various motives chosen will follow aspects of the culture and trust of the "Orang Ulu" community in nature. In general, Kalong motifs among the "Orang Ulu" community are divided into four categories of humans and cosmos, fauna, and flora.

\section{RESEARCH METHODOLOGY}

The research methodology used by researchers in carrying out this research. It is intended to explain how this research is conducted, the data is obtained and analyzed to obtain accurate and authentic information and data. This research methodology is used to provide an approach on the specific method or way an issue or problem can be solved or can be answered to ensure that the information obtained is reasonable and supported by the data obtained. This is very necessary to form a methodology of good research, thus producing quality research. Therefore, research methods are an aspect 
or a method that serves to solve every problem that exists in research done by a person or researcher.

Overall, in carrying out this research, the researchers used a qualitative method approach. Conducting qualitative research is a method where the researchers have to make observations down to the $\mathrm{f}$ ield study site and conduct interviews with residents in the selected area. Recognize and understand the Motifs in Art of The Uma Ukit Koyan Community in Belaga, Sarawak. Researchers conducted this research through online interviews with residents in the tribal village of the Uma Ukit Koyan in Belaga, Sarawak to obtain complete research information.

However, on the other hand, obtaining information in writing and orally, researchers will also obtain photographs related to art motifs that have been produced from the informants interviewed. Therefore, this situation can show more clearly the artistic motifs produced by the Uma Ukit Koyan Community in Belaga, Sarawak.

\section{EMPIRICAL RESULTS AND ANALYSIS}

The motifs art of the community Uma Ukit Koyan was known as Hudok. Most of the "Orang Ulu" from Uma Ukit uses Hudok as part of their culture. They often use the Hudok motif to wall decorations, bukui (traditional women's jewellery), singau (traditional hats), avet (traditional carrying bag), salung (tombs), etc. There are many motifs of hudok which are hudok sengiro, hudok Asok/asu, hudok pusung tubak, and hudok lino/kelunan. Most hudok motifs are mostly used by people of royal descent.

Furthermore, the Uma Ukit Koyan community has rattan decorations on their house walls that take six months or more to complete per block. If the house block is completed, they will complete a nomination to the Malaysian Book of Records. They have been appeared in RTM television channels because of their distinctive decorations, with each block creating a different design. Sir Belarek is the inventor of ruai rattan. Sir Belarek was the person who began ruai decoration with rattan and was initially placed on a ruai chair. 


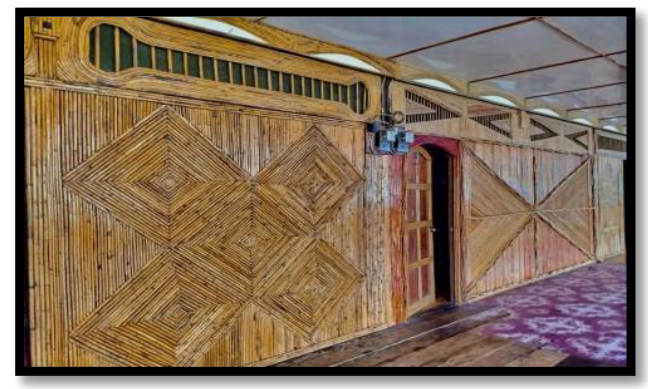

Figure 1: One of Uma Ukit motifs Resource: Informant Miss Shafinaz

Each block provides unique decorations for both the outside and inside of the house. This house belongs to one of them, Madam Suti Bawa, according to Figure 1, 2, and 3. Madam Suti Bawa was one of Uma Ukit's most important people. Madam Suti Bawa was the daughter of a village chief in the past, and her husband took over as village chief. The name of the village chief is Sir Maren Uma Ukit Ngaret Lijap. If an issue comes, madam Suti's home will be used as a gathering spot. According to sources, only the community of Uma Ukit creates wall decorations.

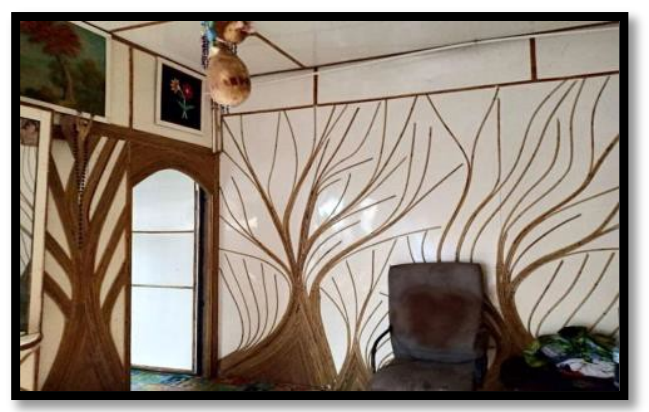

Figure 2: Sir Belarek House Resource: Informant Miss Shafinaz

The motifs of wall decoration are mostly inspired by flora and fauna, gong, parang, Sarawak vase, etc. One of the decorations at the informant grandmother's house named Unang Gasai was inspired by flora and fauna and eyes like Figure 12. Most decorations at their house were made by women of the Uma Ukit community while men will search for rattan. The cost of production per door 1000 ringgit includes transport and decorations materials. The rattan was called "weihogo" or rattan "letikan". 


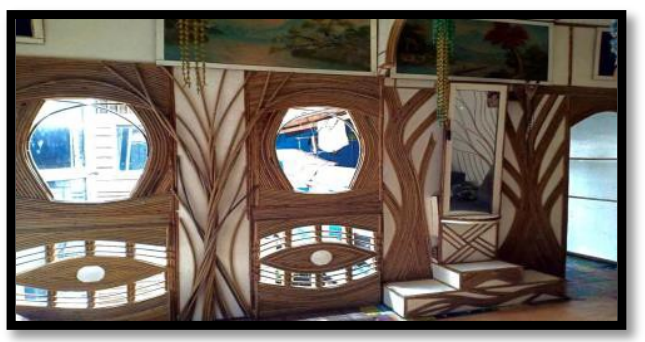

Figure 3: Sir Belarek House, Eyes Motif Resource: Informant Miss Shafinaz

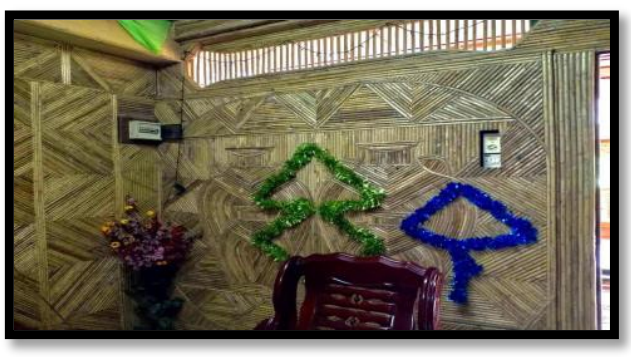

Figure 4: The Motif Sarawak Vase, one of community Uma Ukit Resource: Informant Nur Shafinaz

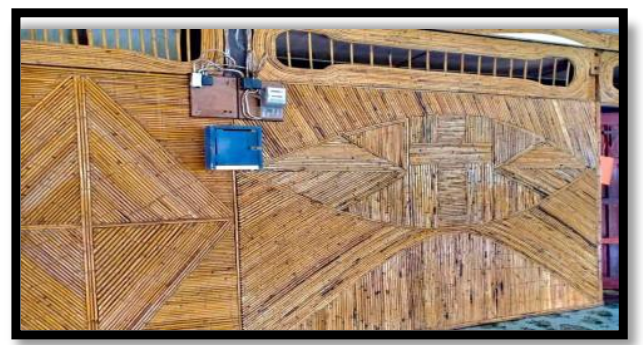

Figure 5: Unang Gasai Outside Decorations Inspired by Eyes Resource: Informant Nur Shafinaz

\subsection{Hudok Sengiro}

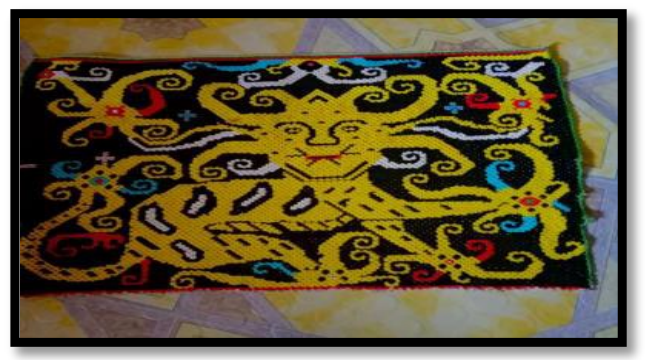

Figure 6: Hudok Sengiro Resource: Informant Madam Suti Bawa

Hudok Sengiro was also known as the lion motifs that rarely use by the Uma Ukit community that was made of beads and was called "dihei bukok". According to their beliefs, Sengiro was the king of the jungle and the Hudok Sengiro motifs cannot be used at will by other residents of Uma Ukit. Those motifs only can be used by someone of royal descent. The use of this hudok can be used as a place to put the baby. This 
type of hudok sengiro was called "Avet", it is a kind of carrying bag. "Avet" is also used for children of royal descent.

According to informant Madam Suti Bawa, ordinary people cannot use this motif, and the completion time ranges from two to three months. However, "Avet" can be used by other Uma Ukit communities, but with different motifs and not motifs hudok sengiro. These motifs would be presented to members of other communities by people of royal descent. It was intended to convey their status as descendants of royalty.

These motifs are commonly seen during festive and "keramaian" occasions. The Uma ukit people's festival is known as "Alo bhuket."

\subsection{Hudok Asok/Asu}

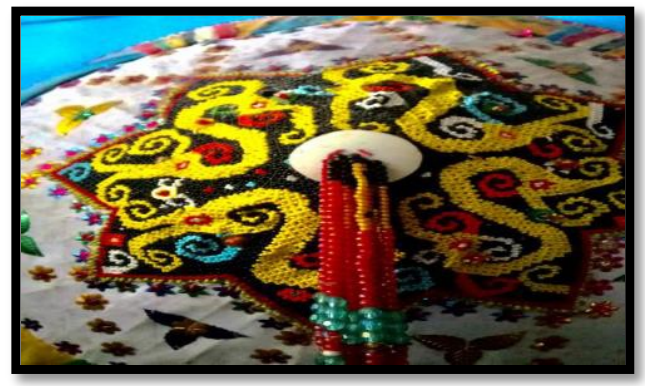

Figure 7: Singau Hudok Asok/Asu Resource: Informant Madam Suti Bawa

Hudok Asok or Asu is another motif that can only be used by people of royal descent. According to Uma Ukit beliefs, using this motif or ordinary people using this motif may cause them to go insane. Hudok Asu, also known as the dog motif, was one of the motifs used for singau. Singau was a traditional hat worn by women or as a complement to other accessories. Most of Singau Hudok Asok or Asu are used as home decorations, such as hanging on the wall. Women in Uma Ukit would wear the usual and has no meaning Singau while gardening and harvesting. Singau has no meaning other than to demonstrate the creativity of Community Uma Ukit such as Figure 8.

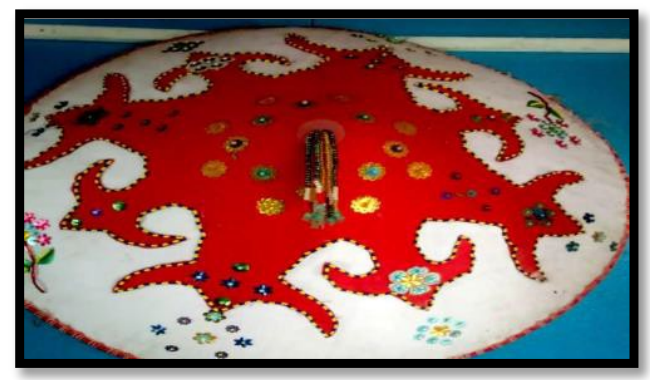

Figure 8: Singau Uma Ukit Resource: Informant Madam Suti Bawa 


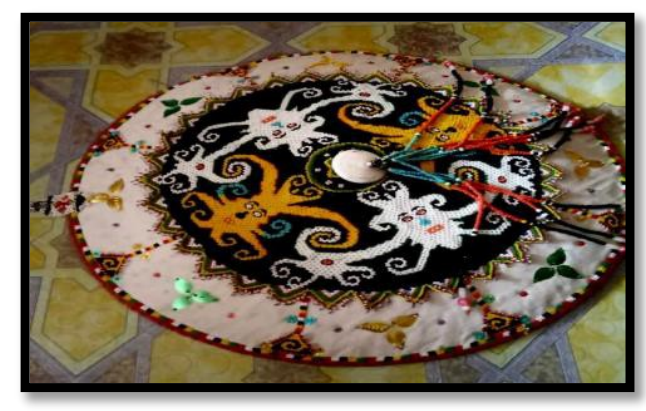

Figure 9: Hudok Lino/Kelunan Resource: Informant Madam Suti Bawa

According to Madam Suti Bawa, Hudok Lino or Kelunan simply means "people." The hudok lino motif is $f$ requently used by the community that is affordable and also has skills in weaving or carving. Hudok Lino or Kelunan is also commonly used as an accessory to "Orang Ulu" traditional attire, wall decorations, or even in beauty queen contests. Hudok Lino or Kelunan has also been used in Uma Ukit's "Alo Bhuket" festival.

\subsection{Hudok Pusung Tubak}

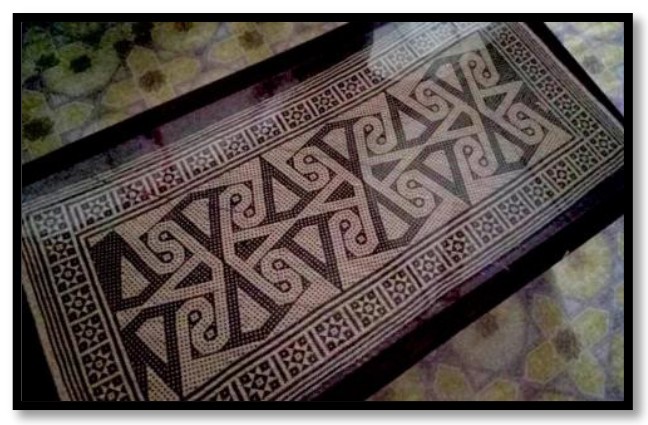

Figure 10: Hudok Pusung Tubak Resource: Informants Madam Suti Bawa

According to Madam Suti, Hudok Pusung Tubak has no special meaning but is commonly used as a decoration and to gather with other members of the community. The hudok pusung tubak motif was inspired by flora and fauna as well as hereditary inspiration. Rattan, tevangau leaves, parang, knife, silet, tui, tapak and aguk (self-made knife) are the materials used to make mats. They will use "weletikan" to thin the rattan. In the past, the Uma Ukit community used clay to colour the mat, but now they use dye. To make the rattan dark, tevangau leaves and clay will be boiled for 1 day and stored overnight. 


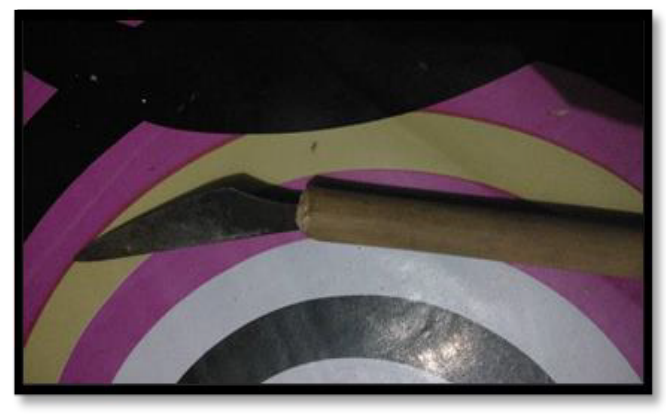

Figure 11, Aguk

Resource: Informant Nur Shafinaz

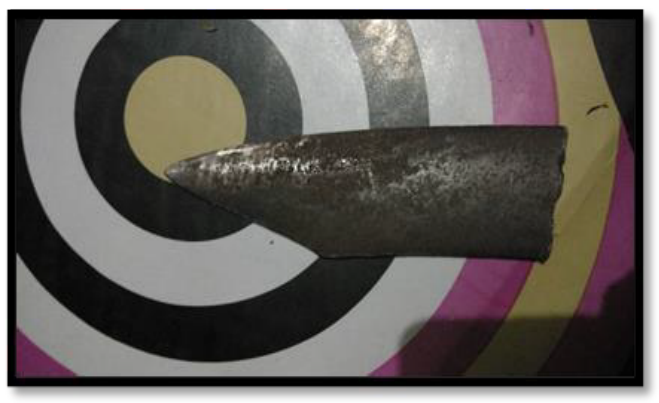

Figure 12: Tapak

Resource: Informant Nur Shafinaz

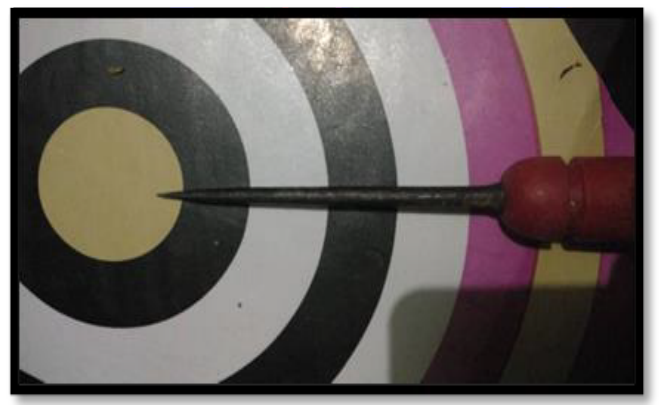

Figure 13: Silet

Resource: Informant Nur Shafinaz

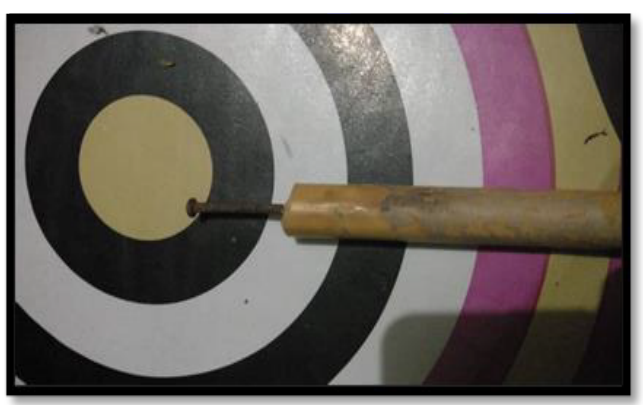

Figure 14: Tui

Resource: Informant Nur Shafinaz 


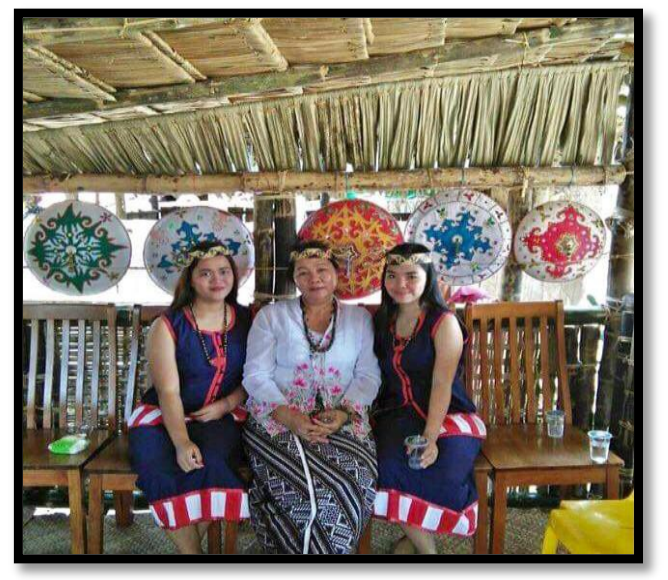

Figure 15: Madam Suti Bawa with Nur Shafinaz Resource: Informants Nur Shafinaz

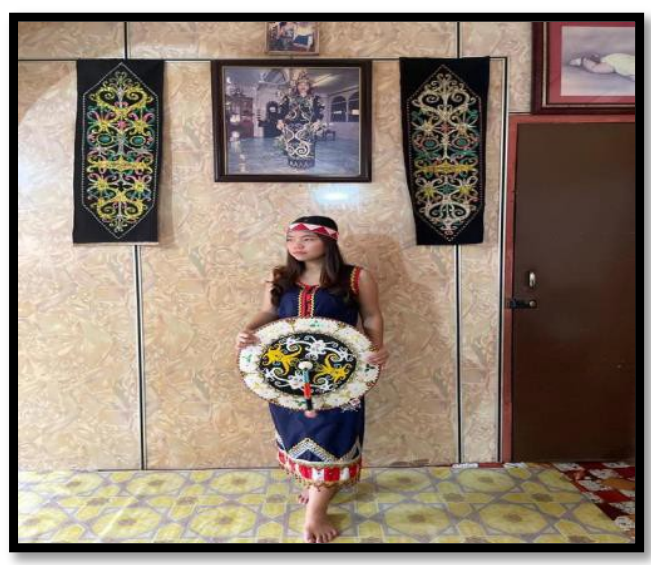

Figure 16: Nur Shafinaz wearing Pigon Resource: Informants Nur Shafinaz

\section{CONCLUSION}

To maintain the uniqueness of Hudok Motifs, the community must learn and re-apply the art of motifs that have been produced so that the value of its uniqueness does not disappear in the era of the country which is increasingly advanced with the existence of various advanced technologies. Maintaining the uniqueness that has been created in a society must be maintained to provide exposure to future generations so that something unique can be carried to the next generation. This situation can also be stated that if it has something so unique such as the Hudok Motif, it not only attracts the interest of the local community but will also be able to attract the interest of the community from abroad if maintained. With that, it can show something unique in this country. Therefore, stakeholders can also work with residents who produce Hudok Motifs in marketing each product that has been produced to a higher level to help introduce the motif to other communities. 


\section{REFERENCES}

1. Abdullah, N. (2019, Disember 15). Terokai keunikan Bumi Kenyalang. Retrieved from BHonline:https://www.bharian.com.my/hujungminggu/santai/2019/12/638824/terokai-keunikan- bumi-kenyalang

2. Ding, L. (2011). The Use of Rhinoceros Hornbill Birds in Orang Ulu Arts Penggunaan Burung Kenyalang Dalam Kesenian Orang Ulu. Kuching, Sarawak: Universiti Malaysia Sarawak.

3. Dugun, D. L. (2019, September 12). Sarawak contoh terbaik dalam perpaduan antara kaum. Retrieved from Sarawakvoice News: https://sarawakvoice.com/2019/09/12/sarawak-contoh-terbaik- dalamperpaduan-antara-kaum/

4. Jau, M. I. (2004). Traditional Motives of The Kayan/Kenyah Community / Motif Tradisional Masyarakat Kayan/Kenyah. Kuching, Sarawak: Universiti Malaysia Sarawak.

5. Kujat, N. S. (2021, Januari 2). Cerita pagi Sarawak - Ruai Rotan Uma Ukit . Retrieved from Berita RTM: https://www.youtube.com/watch?v=xpyYz76zQ6I\&t=2s

6. Lydia, P., Intan, K., \& Harozila, R. (2015). The Motifs of Kalong in Sarawak. Jurnal Seni dan Pendidikan Seni, 3, 127-140.

7. News, A. A. (2019, Julai 18). Mengangkat legasi etnik Sarawak dalam perniagaan pakaian . Retrieved from Astro awani : https://www.astroawani.com/gaya-hidup/mengangkat-legasi-etnik- sarawakdalam-perniagaan-pakaian-212978

8. Roselind, Wan., Sumathi, R., \& Bromely, R. (2015). What is the point of us taking? Ethnic language and ethnic identity in northern Borneo, Malaysia. Journal of Humanities and Social Sciences, 04(01), 109-120.

9. Sahari, F. (2012). Sustainability of Orang Ulu Crafts. Kuching, Sarawak: Research Innovation for Malaysia, Borneo and Australia (RIMBA3).

10. Salmah, O., Philip, L., \& Ribka, A. (2016). Etnik dan pembentukan landskap budaya Malaysia: Seni anyaman tikar Orang Ulu Sarawak. Journal of Society and Space, 10(12), 21-28.

11. Sarawak, E. (2020, September 30). Sarawak energy updates Bakun resettlement scheme community on social investment initiatives. Retrieved from Sarawak energy: https://www.sarawakenergy.com/media-info/mediareleases/2020/sarawak-energy-updates-bakun-resettlement-schemecommunity-on-social-investment-initiatives 
12. Shafinaz, N., \& Bawa, S. (2021, April 12). The Motif of Design in The Community of Uma Ukit Belaga, Sarawak. (N. H. Rosli, Interviewer) 